\title{
Hypoglycemic Activity of the Fruit of the Momordica charantia in Type 2 Diabetic Mice
}

\author{
Toshihiro Miura ${ }^{1, *}$, Chisa ItoH ${ }^{1}$, Naoki Iwamoto ${ }^{1}$, Motoshi Kato $^{1}$, Masaomi Kawai ${ }^{1}$, \\ Sang Rae PARK ${ }^{2}$ and Ikukatsu SuZUKI ${ }^{1}$ \\ ${ }^{1}$ Department of Clinical Nutrition, and \\ ${ }^{2}$ Graduate School of Medical Imaging, Suzuka University of Medical Science, \\ 1001-1 Kishioka, Suzuka, Mie 510-0293, Japan
}

(Received March 15, 2001)

\begin{abstract}
Summary The antidiabetic activity of Momordica charantia L. (Cucurbitaceae) was investigated in KK-Ay mice, an animal model with type 2 diabetes with hyperinsulinemia. The water extract of the fruit of Momordica charantia L. (MC) reduced the blood glucose of KK-Ay mice 3 weeks after oral administration $(p<0.01)$ and also significantly lowered the serum insulin of KK-Ay mice under similar conditions $(p<0.01)$. However, MC did not affect the blood glucose in normal mice. MC-treated KK-Ay mice blood glucose significantly decreased in an insulin tolerance test. Moreover, the muscle content of facilitative glucose transporter isoform 4 (GLUT4) protein content in the plasma membrane fraction from muscle significantly increased in the orally MC-treated mice when compared with that of the controls $(p<0.01)$. These results suggest that the antidiabetic effect of MC is derived, at least in part, from a decrease in insulin resistance because of the increase of GLUT4 protein content in the plasma membrane of the muscle.
\end{abstract}

Key Words hypoglycemic effect, Momordica charantia, Cucurbitaceae, insulin resistance, GLUT4

Despite much progress in the management of diabetes mellitus by synthetic drugs, the search for indigenous natural antidiabetic agents is ongoing. The plant kingdom is a wide field in which to look for effective oral hypoglycemics. More than 400 species have been reported to display hypoglycemic effects, but only a few have been investigated (1-3).

In Okinawa, where many people live to an advanced age, the inhabitants eat fruits of the Momordica charantia L. The fruits of the Momordica charantia L. (Cucurbitaceae) (named Nigauri in Japanese), a plant widely used in traditional medicine as an antidiabetic agent, has been shown to lower blood glucose in laboratory animals $(4-10)$. However, an adequate characterization of this effect has yet to be made. So far, experiments have been performed on a type 1 diabetes model animal, but no study has been performed on genetically type 2 diabetes models.

Glucose transport across the plasma membrane is mediated by carrier proteins termed glucose transporters $(11,12)$. Recent cDNA cloning has demonstrated that the facilitative glucose transporters comprise a family of structurally related proteins with differing tissue distribution (13). The gene expression and protein content of glucose transporters have been found to be altered under pathological conditions such as diabetes mellitus (13-15).

In the present study, we have examined the effect of Momordica charantia L. on blood glucose and the effect

\footnotetext{
* To whom correspondence should be addressed.
}

of insulin resistance, and we also investigated the protein content of the muscle glucose transporter isoform 4 (GLUT4) to elucidate the mechanism of the antidiabetic effect.

\section{MATERIALS AND METHODS}

The fruit of the Momordica charantia used in this experiment was obtained in a market in Peru by Coperunix Japan INC Co., Ltd. (Tokyo, Japan). One hundred grams of the fruit was extracted with $2 \mathrm{~L}$ of water $\left(40^{\circ} \mathrm{C}, 2 \mathrm{~h}, 2\right.$ times). The water extracts were lyophilized (MC) and stored at room temperature until use.

Animals. Adult male ddY mice (SLC, Shizuoka, Japan) weighing 22-25g and KK-Ay mice (CLEA Japan, Tokyo, Japan), 12 weeks old, were used. KK-Ay mice with blood glucose level above $300 \mathrm{mg} / 100 \mathrm{~mL}$ were considered to be diabetic in this study. The mice were housed in an air-conditioned room at $22 \pm 2^{\circ} \mathrm{C}$ with a 12-h light/12-h dark cycle (light: $9: 00$ a.m. to $9: 00$ p.m.). The animals were kept in the experimental animal room for $7 \mathrm{~d}$ with free access to food (CE-2, CLEA Japan) and water (tap water). Blood samples were drawn from the cavernous sinus with a capillary to determine blood glucose levels under nonanesthesia and nonfasting. MC was dissolved in distilled water. The studies were started at 10:00-11:00 a.m., and the blood samples after repeated administration of MC were taken at 10:00-11:00 a.m. The oral administrations of $\mathrm{MC}$ were given on a compulsory basis.

Oral glucose tolerance test. After overnight $(18 \mathrm{~h})$ fasting, KK-Ay mice were given MC orally, and $0.5 \mathrm{~h}$ 
later the glucose $(2 \mathrm{~g} / \mathrm{kg}$ body weight) solution was administered orally. Blood samples were collected before administration of the glucose and 30, 60, and $120 \mathrm{~min}$ later.

Insulin tolerance test. After overnight (18 h) fasting, KK-Ay mice were given MC orally, and $0.5 \mathrm{~h}$ later the insulin $(0.5 \mathrm{U} / \mathrm{kg}$ body weight) solution was administered subcutaneously. Blood samples were collected before administration of the insulin and at 30, 60, and 120 min later.

Determination of blood glucose and insulin. Blood glucose levels in mice were determined by the glucose oxidase method (16), and serum insulin was measured by the double antibody method (17).

Isolation of hindlimb muscle. The mice were given insulin $(0.5 \mathrm{U} / \mathrm{kg})$ or saline (as controls) subcutaneously, and $0.5 \mathrm{~h}$ later the hindlimb muscle was resected for the experiment.

Plasma membrane (PM) fraction of skeletal muscle. The muscle tissue was placed in a buffer ( 5 mm sodium azide, $0.25 \mathrm{~m}$ sucrose, $0.1 \mathrm{~mm}$ phenylmethylsulfonyl fluoride (PMSF), $10 \mathrm{~mm} \mathrm{NaHCO} 3$ [pH 7.0]) at $4^{\circ} \mathrm{C}$. The subfractionation of muscle membrane was as described by Baron et al. (18), whose procedure was modified from that of Klip et al. $(19,20)$. The muscle was homogenized and centrifuged at $1,000 \times \mathrm{g}$ for $10 \mathrm{~min}$, and the supernatant was saved. The resulting pellet was resuspended in the buffer and rehomogenized with a glass homogenization tube. The supernatant was combined with the first supernatant and centrifuged at $9,000 \times g$ for $10 \mathrm{~min}$. The resulting supernatant was then centrifuged at $190,000 \times g$ for $60 \mathrm{~min}$. These membranes were applied to a discontinuous sucrose gradient containing $25 \%, 30 \%$, and $35 \%$ sucrose (wt/vol) solutions and was centrifuged at $190,000 \times g$ for $16 \mathrm{~h}$. Plasma membranes were collected in $25 \%$ sucrose gradients, resuspended in the buffer, pelleted by centrifugation at $190,000 \times g$ for $60 \mathrm{~min}$, and resuspended in the buffer.

Western blot analysis. The antibody used in the Western blotting (East Acres, USA) was raised against a synthetic peptide corresponding to the $\mathrm{COOH}$-terminal domain of mouse GLUT4 (12 amino acid peptide), as reported by James et al. (21) (No reaction against brain or liver. Does not cross-react with GLUT1 or GLUT2 tested.) To prepare the total membrane particulate fractions, the mice muscles were excised and 1 to $2 \mathrm{~g}$ of muscle slice was homogenized in $25 \mathrm{~mL}$ of $10 \mathrm{~mm}$ Tris$\mathrm{HCl}, 1 \mathrm{~mm}$ phenylmethyl sulphonyl fluoride, and 1,000 units/mL of aprotinin (22). The homogenates were then centrifuged at $700 \times \mathrm{g}$ for $10 \mathrm{~min}$ at $4^{\circ} \mathrm{C}$ to sediment the fraction containing mainly the nuclei and mitochondria. The resulting supernatant was centrifuged at $13,000 \times g$ for $20 \mathrm{~min}$ at $4^{\circ} \mathrm{C}$ to yield a pellet designated as the membrane fraction of the muscle in this study. The membrane fractions $(30 \mu \mathrm{g})$ prepared were suspended in 1\% SDS and $50 \mathrm{~mm}$ dithiothreitol and subjected to SDS-polyacrylamide (9\%) gel electrophoresis. Electrophoretic transfer to nitrocellulose paper and detection of the immunocomplex with enhanced chemiluminescence (Amersham, Buckinghamshire,
UK) were carried out, as previously described (23). The sheet was exposed on RX X-ray film and an intensifying screen (Fuji, Tokyo, Japan). The prestained molecular weight standard (Bio-Rad, Richmond, VA, USA) was used for estimation of the molecular weight. The experiments were performed at least twice for each tissue with similar results.

Statistical analysis. All the data were expressed as mean $\pm S E$, and Student's $t$-test and ANOVA were used for the statistical analysis. The values were considered significant when the $p$ value was less than 0.05 .

\section{RESULTS}

The effect of MC on blood glucose in $K K-A y$

The effect of MC injected per os to KK-Ay mice is shown in Fig. 1. MC-treated animals $(100 \mathrm{mg} / \mathrm{kg}$ body weight) showed lower blood glucose levels from 1 to 3 weeks after the administration ( 1 week: $p<0.05,2$ and 3 weeks; $p<0.01$ ). The serum insulin level in $\mathrm{MC}$ treated mice decreased 3 weeks after the administration $(p<0.01)$ (Fig. 2). However, MC did not affect the blood glucose in normal mice (Fig. 3).

\section{Oral Glucose Tolerance Test}

The effect of MC on glucose tolerance is shown in Fig. 4. MC-treated mice (100 $\mathrm{mg} / \mathrm{kg}$ body weight) showed no significant decrease in blood glucose after 30, 60, and $120 \mathrm{~min}$ when compared with controls.

Insulin Tolerance Test

MC-treated mice (100 mg/kg body weight, per os) showed a significant decrease in blood glucose after 30 and $60 \mathrm{~min}$ compared with controls (30 min: $p<0.01$, 60 min: $p<0.01$ ) (Fig. 5).

Muscle GLUT4 Protein

The Effects of MC on muscle PM fraction of GLUT4 protein levels in both control and MC-treated KK-Ay mice are demonstrated in Fig. 6. The quantitation of GLUT4 protein in membrane in muscle was assessed by Western blotting in the mice. Quantitation of the

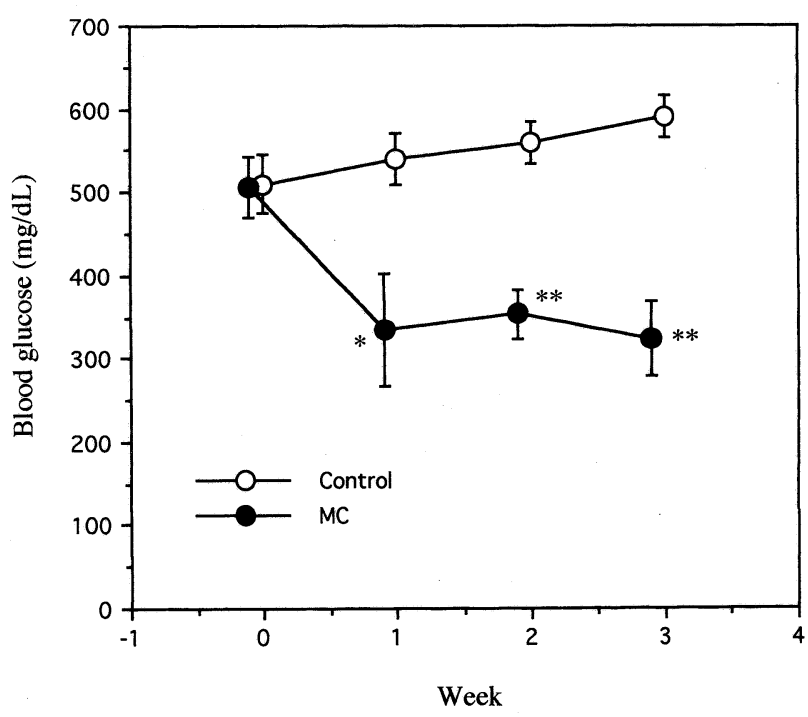

Fig. 1. Effects of MC on blood glucose in KK-Ay mice. Each value represents the mean \pm SE of 5 to 6 mice. Significantly different from prevalue, ${ }^{*} p<0.05,{ }^{* *} p<$ 0.01 (by ANOVA). 


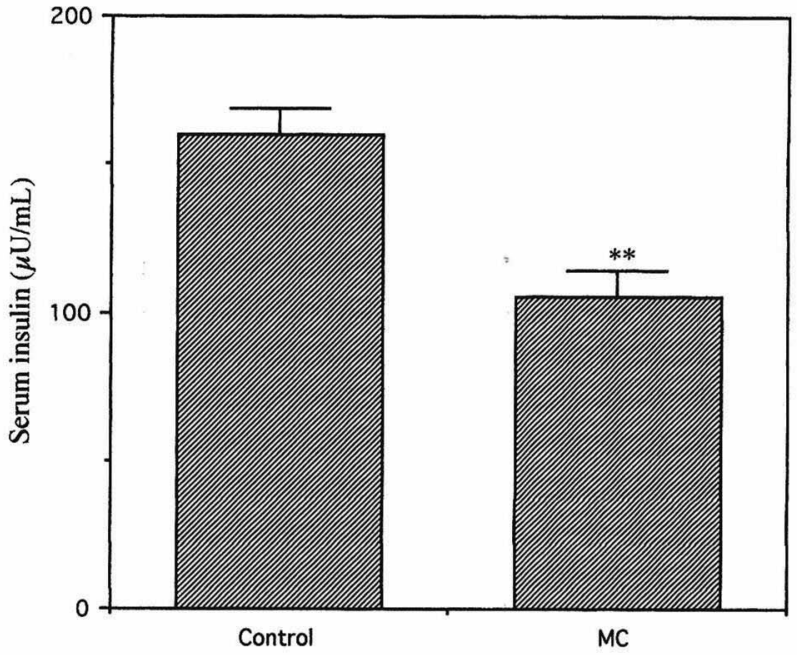

Fig. 2. Effect of MC on serum insulin in KK-Ay mice. Each value represents the mean \pm SE of 5 to 6 mice. Significantly different from control, ${ }^{* *} p<0.01$.

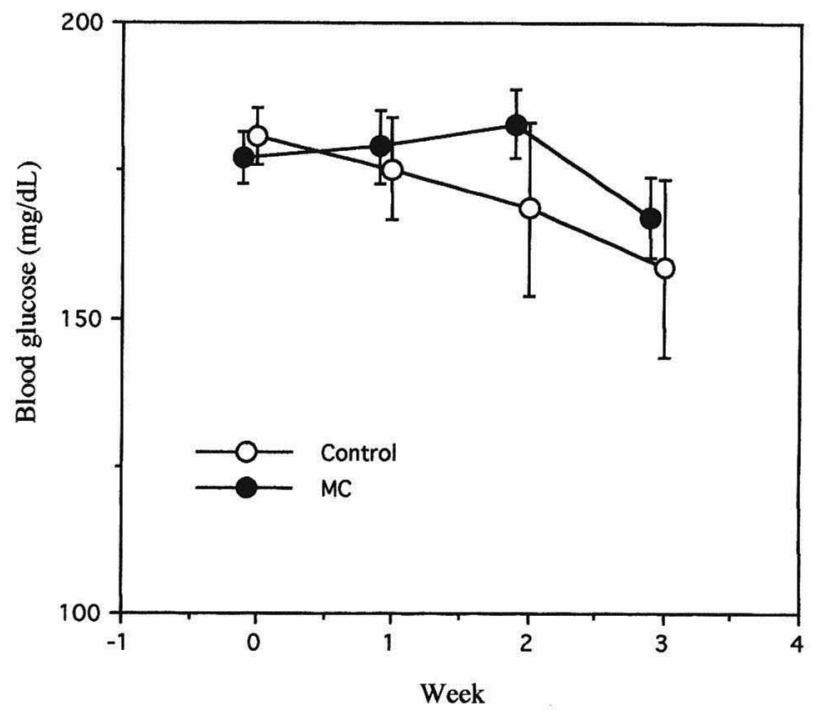

Fig. 3. Effects of MC on blood glucose in normal mice. Each value represents the mean \pm SE of 5 to 6 mice.

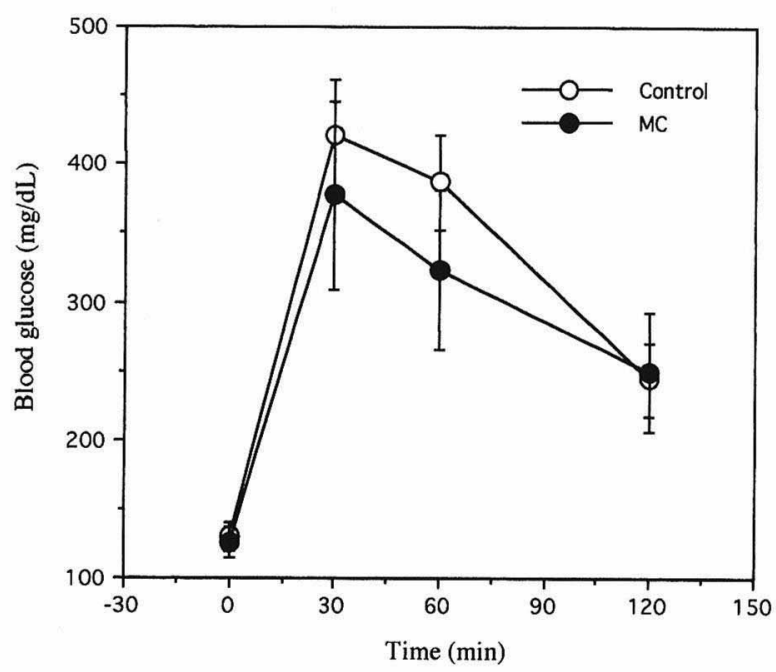

Fig. 4. Effect of MC on glucose tolerance test in KK-Ay mice. Each value represents the mean $\pm S E$ of 5 mice.

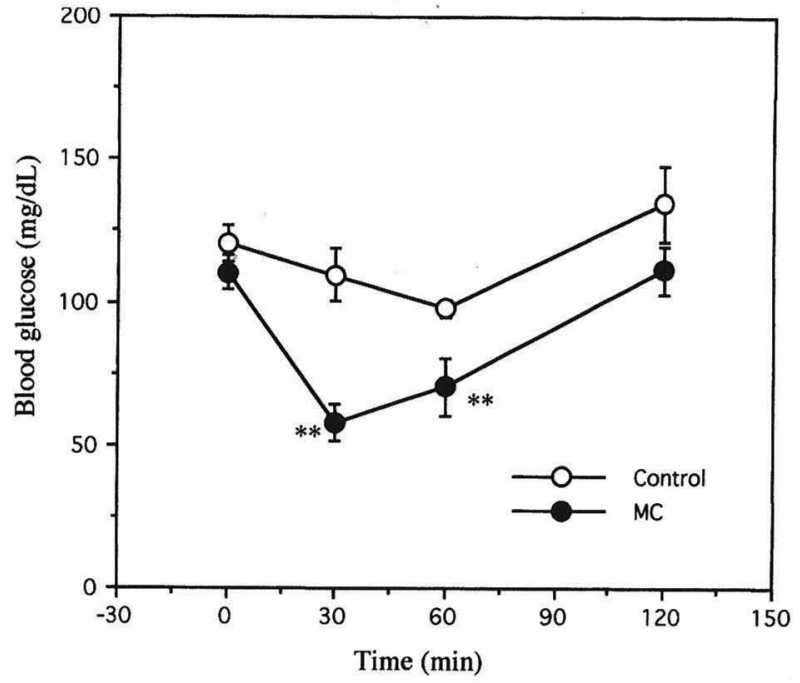

Fig. 5. Effect of MC on insulin tolerance test in $\mathrm{KK}-\mathrm{Ay}$ mice. Each value represents the mean \pm SE of 5 to 6 mice. Significantly different from control, ${ }^{* *} p<0.01$ (by ANOVA).

\section{Control MC}

\section{GLUT4}

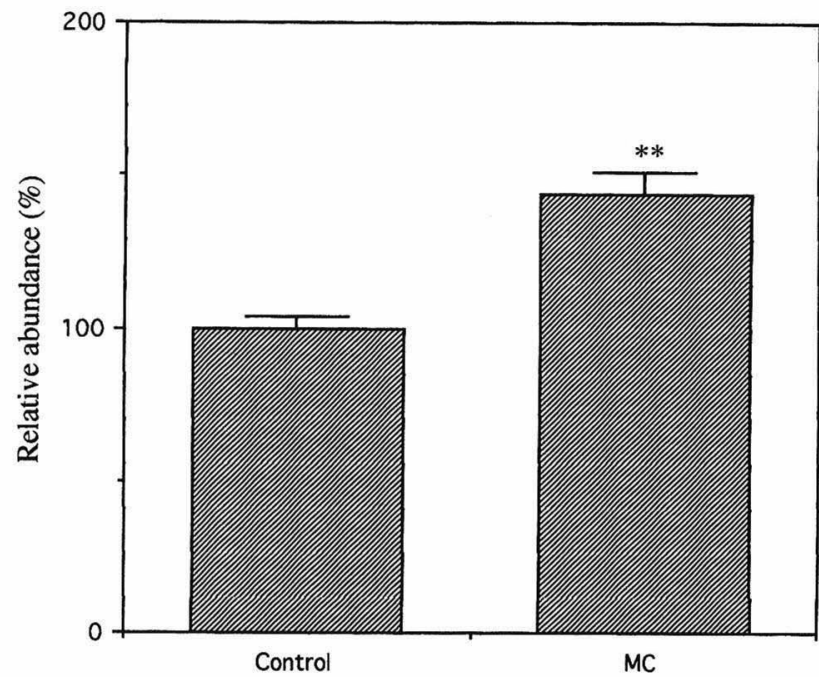

Fig. 6. Effect of MC on GLUT4 content in mouse skeletal muscle. Each value represents the mean \pm SE of 5 mice. Significantly different from control, ${ }^{* *} p<0.01$.

GLUT4 glucose transporter band isolated from nitrocellulose paper demonstrated that the relative amount of GLUT4 protein in the muscle from MC treated mice was $144 \%$ of that observed in the control mice $(p<0.01)$ (Fig. 6).

\section{DISCUSSION}

This study clearly showed that the water extract of the fruits of Momordica charantia (MC) produces a consistent hypoglycemic effect. In the preliminary study, we 
examined the dose-dependence $(4,20,100 \mathrm{mg} / \mathrm{kg}$ body weight) $7 \mathrm{~h}$ after the single administration of $\mathrm{MC}$ and found that the most effective dose was $100 \mathrm{mg} / \mathrm{kg}$ $\left(\mathrm{EC}_{50}=1.26 \mathrm{mg} / \mathrm{kg}\right.$ ) (data not shown). It seems very likely that MC displays hypoglycemic activity after the metabolic process because MC lowered blood glucose $7 \mathrm{~h}$ after the administration. We examined the therapeutic effects of MC on hyperglycemia in KK-Ay mice, an animal model with type 2 diabetes mellitus. KK-Ay mice, which are known for genetically induced diabetes, including ob/ob mice (24) and KK mice (25), were hyperinsulinemia as a result of insulin resistance (26). After treatment with MC, hypoglycemia resulted with reduced serum insulin. These results indicate that $\mathrm{MC}$ improves hyperinsulinemia in type 2 diabetes. The insulin resistance in peripheral tissues is known to be one of the major pathogenic factors of type 2 diabetes. The finding that MC decreases blood insulin level in KK-Ay mice is important.

MC-treated KK-Ay mice also had lower blood glucose in the insulin tolerance test and hyperinsulinemia was improved. Insulin $(0.5 \mathrm{U} / \mathrm{kg})$-treated $\mathrm{KK}$-Ay mice had no lower blood glucose because of insulin resistance in the peripheral tissues, suggesting that MC lessens insulin resistance. Higashino et al. reported that MC decreased the blood glucose in streptozotocin-induced diabetic rats, an animal model of type 1 diabetes, and suggested that the hypoglycemic mechanism of MC was due to a decrease in glucose absorption in the small intestine (7). Day et al. reported that MC decreased blood glucose in mice with no changes in insulin secretion and suggested that the hypoglycemic mechanism was due to an increase of the glucose utilization in peripheral tissues (6). From these findings, it seems very likely that the hypoglycemic mechanism of $\mathrm{MC}$ is due to the reduction of insulin resistance by decreasing the glucose absorption in the small intestine. However, our data indicated that MC decreased the blood glucose in normal mice. Moreover, MC did not affect the blood glucose in a glucose tolerance test after repeated administration. It is possible to directly activate the insulin receptor in peripheral tissues and thereafter to increase the glucose uptake.

Furthermore, we examined the effect of $\mathrm{MC}$ on GLUT4 glucose transporter in mouse muscle, since it has been reported that GLUT4 plays a crucial role in the muscle process of glucose uptake. MC increased GLUT4 protein content of muscle in KK-Ay mice. It is known that GLUT4 and GLUT1 are present in skeletal muscle. However, MC did not affect GLUT1 protein content in skeletal muscle (data not shown). From these findings, it is very likely that the hypoglycemic effect of MC is derived, at least in part, from the decrease in insulin resistance, presumably because of the increase of GLUT4 protein content in total muscle membrane.

As for the hypoglycemic compounds of MC, Ali et al. reported that MC contained nonsapogenin, which may have contributed to the reduction of blood glucose in streptozotocin-induced diabetic rats (9). Lolkar et al. reported that the hypoglycemic principle was charantin
(5). In the present study, these compounds could be related to the antidiabetic activity.

Further study would show how MC could become a useful drug in the treatment of diabetes through this unique therapeutic mechanism. The above experimental results suggest that the antidiabetic activity of $\mathrm{MC}$ supports the traditional medical use of type 2 diabetes.

\section{REFERENCES}

1) Aslam M, Stockley IH. 1979. Interaction between curry ingredient (karela) and drug (chlorpropamide). Lancet 1 (8116): 607.

2) Cupts SS, Seth CB. 1982. Effect of Momordica charantia Linn. (karela) on glcuose tolerance in albino rats. $J$ Indian $M A$ 39: 581-584.

3) Menon PVG, Kurup PA. 1974. Hypolipidemic action of the Polysaccharide from Phaseolus mungo. Atherosclerosis 19: 315.

4) Upadhyaya GL, Ajai Kumar, Pant MC. 1985. Effect of Karela as hypoglycemic and hypocholesterolemic agent. J Díab Assoc Ind 25: 12-15.

5) Lolkar MM, Rajaramn Rao MR. 1966. Pharmacology of a hypoglycaemic principle isolated from the fruits of Momordica charantia Linn. Indian J Pharm 28: 129-133.

6) Day C, Cartwright T, Provost J, Bailey CJ. 1990. Hypoglycemic effect of Momordica charantia extracts. Planta Med 56: 426-429.

7) Higashino H, Suzuki A, Tanaka Y, Pootakham K. 1992. Hypoglycemic effect of Siamese Momordica charantia and Phyllanthus urinaria extracts in streptozotocin-induced diabetic rats. Folia Pharmacol Jpn 100: 415-421.

8) Srivastava Y, Venkatakrishna-Bhatt H, Verma Y, Venkaiah K. 1993. Antidiabetic and adaptogenic properities of Momordica charantia extract: an experimental and clinical evaluation. Phytotherapy Res 7: 285-289.

9) Ali L, Khan AK, Mamun MI, Mosihuzzaman M, Nahar N, Nur-e-Alam M, Rokeya B. 1993. Studies on hypoglycemic effects of fruit pulp, seed, and whole plant of Momordica charantia on normal and diabetic model rats. Planta Med 59: 408-412.

10) Srivastava Y, Venkatakrishna-Bhatt H, Verma Y. 1988. Effect of Momordica charantia Linn. pomous aqueous extract on cataractogenesis in murrin alloxan diabetics. Pharmacol Res Commun 20: 201-209.

11) Wheeler TJ, Hinkle PC. 1985. The glucose transporter of mammalian cells. Ann Rev Physiol 47: 503-517.

12) Simpson IA, Cushman SW. 1986. Hormonal regulation of mammalian glucose transport. Ann Rev Biochem 55: 1059-1089.

13) Bell GI, Kayano T, Buse JB, Burant CF, Takeda J, Lin D, Fukumoto H, Seino S. 1990. Molecular biology of mammalian glucose transporters. Diabetes Care 13: 198-208.

14) Berger J, Biswas C, Vicario PP, Strout HV, Seperstein R, Pilch PF. 1989. Decreased expression of the insulin-responsive glucose transporter in diabetes and fasting. Nature 340: 70-72.

15) Sivitz WI, Desautel SL, Kayano T, Bell GI, Pessin JE. 1989. Regulation of glucose transporter messenger RNA in insulin-deficient states. Nature 340: 72-74.

16) Stevens JF. 1951. Determination of blood glucose by glucose oxidase method. Clin Chim Acta 32: 199-201.

17) Bailei CJ, Ahmed-Sorour H. 1980. Role of ovarian hormones in the long-term control of glucose homeostasis. 
Diabetologia 19: 475-481.

18) Baron A, Zhu JS, Zhu JH, Weldon H, Maianu L, Garvey MT. 1995. Glucosamine induces insulin resistance in vivo by affecting GLUT4 translocation in skeletal muscle. Implications for glucose toxicity. J Clin Invest 97: 2792-2801.

19) Klip A, Ramlal T, Young DA, Holloszy JO. 1987. Insulinstimulated glucose transporters in rat hindlimb muscles. FEBS Lett 224: 224-230.

20) Klip A, Ramlal T, Bilan PJ, Cartee GD, Gulve EA, Holloszy JO. 1990. Recruitment of GLUT4 glucose transporter by insulin in diabetic rat skeletal muscle. Biochem Biophys Res Commun 172: 728-736.

21) James DE, Strube M, Mueckler M. 1989. Molecular cloning and characterization of an insulin-regulatable glucose transporter. Nature 338: 83-87.

22) Oka Y, Asano T, Shibasaki A. 1990. Increased liver glucose transporter protein and mRNA in streptozotocininduced diabetic mice. Diabetes 39: 441-446.

23) Perez C, Albert I, DeFay K. 1990. A nonsecretable cell surface mutant of tumor necrosis factor (TNF) kills by cell-to-cell contact. Cell 63: 251-258.

24) Coleman DL. 1982. Diabetes-obesity syndromes in mice. Diabetes 31 (Suppl 1): 1-6.

25) Nakamura M. 1962. A diabetic strain of the mouse. Proc Jpn Acad 38: 348-352.

26) Nishimura M. 1969. Breeding of mice strains for diabetes mellitus. Exp Anim 18: 147-157. 